\title{
Allelotype of squamous cell carcinoma of the head and neck: fractional allele loss correlates with survival
}

\author{
JK Field ${ }^{1}$, H Kiaris ${ }^{1.2}$, JM Risk ${ }^{1}$, C Tsiriyotis ${ }^{1.2}$, R Adamson' ${ }^{1}$ V Zoumpourlis ${ }^{1.2}$, H Rowley ${ }^{1.3}$, \\ K Taylor ${ }^{1}$, J Whittaker, P Howard $^{5}$, JC Beirne ${ }^{6}$, JR Gosney ${ }^{7}$, J Woolgar ${ }^{1}$, ED Vaughan ${ }^{1.6}$, \\ DA Spandidos ${ }^{2}$ and AS Jones ${ }^{3}$
}

\begin{abstract}
${ }^{1}$ Molecular Genetics and Oncology Group, Department of Clinical Dental Sciences, The University of Liverpool, Liverpool L69 $3 B X, U K ;{ }^{2}$ National Hellenic Research Foundation, 48 Vas. Constantinou Avenue, GR-11635 Athens, Greece; ${ }^{3}$ Department of Otorhinolaryngology, The University of Liverpool, Liverpool L69 3BX, UK; ${ }^{4}$ Regional Molecular Genetics Laboratory, Alder Hey Children's Hospital, Liverpool L12 2AP, UK, ${ }^{5}$ Regional Cytogenetics Unit, Royal Liverpool University Hospital, Liverpool, UK; ${ }^{6}$ Maxillofacial Unit, Walton Hospital, Rice Lane, Liverpool, UK, ${ }^{7}$ Department of Pathology, The University of Liverpool, Liverpool L69 3BX, UK.
\end{abstract}

\begin{abstract}
Summary Allelic imbalance or loss of heterozygosity ( $\mathrm{LOH}$ ) studies have been used extensively to identify regions on chromosomes that may contain putative tumour-suppressor genes. We have undertaken an extensive allelotype of 80 specimens of squamous cell carcinoma of the head and neck (SCCHN) using 145 polymorphic microsatellite markers on 39 chromosome arms. Allelic imbalances were found most frequently on chromosome arms $3 \mathrm{p}, 9 \mathrm{p}, 17 \mathrm{p}$ and $18 \mathrm{q}$ with over $45 \% \mathrm{LOH}$ and imbalances on 1p, 1q, 2p, 5q, 6p, 6q, 8p. $8 \mathrm{q} .9 \mathrm{q} .11 \mathrm{q}, 13 \mathrm{q}, 17 \mathrm{q}$ and $19 \mathrm{q}$ were found in more than $20 \%$ of SCCHN. These LOH data were analysed against a range of clinicopathological parameters which includied previously untreated and previously treated tumours: correlations were found between $\mathrm{LOH}$ on $9 \mathrm{q}$ and nodes at pathology $(P=0.02)$ and between histopathological grade and $\mathrm{LOH}$ on $12 \mathrm{q}(P=0.02)$ and $13 \mathrm{q}(P=0.01)$. In the group of previously untreated tumours, a correlation was found between site of tumour and LOH on $3 \mathrm{p}(P=0.019)$, and $8 \mathrm{p}(P=0.029)$. while TNM staging correlated with LOH on $3 \mathrm{p}(P=0.019)$ and $17 \mathrm{p}(P=0.016)$. Fractional allele loss (FAL) was calculated for 52 tumours with LOH data on nine or more chromosomal arms and found to have a median value of 0.22 (range $0.0-0.80$ ). Correlations were found between FAL $>$ median value and nodes at pathology $(P=0.01)$ and tumour grade $(P=0.06)$, demonstrating that advanced tumours with lymph node metastasis often had LOH at multiple sites. FAL $>$ median value was found to correlate with a poor survival $(P<0.03)$ and. furthermore. FAL $>$ median value correlated with poor survival in the previously untreated patients $(P<0.019)$. These results indicate that assessment of the accumulation of genetic damage. as provided by allelotype data. provides a useful molecular indicator of the tumour behaviour and clinical outcome.
\end{abstract}

Keywords: head and neck cancer: oral cancer; allelotype: microsatellites: loss of heterozygosity; fractional allele loss

The chromosomal locations of many different putative human tumour-suppressor genes have been identified by loss of heterozygosity (LOH) studies (Rees et al., 1989; Lasko et al., 1991; Latif et al., 1992; Cunningham et al., 1993; Adamson et al., 1994). A number of oncogenic and tumoursuppressor gene functions have been demonstrated in squamous cell carcinoma of the head and neck (SCCHN) (Field et al., 1989, 1991; Field, 1992), and the results of LOH analysis currently point to several novel tumour-suppressor gene sites in this disease (Maestro et al., 1993; Adamson et al., 1994; Ah-See et al., 1994; Field et al., 1994; Kiaris et al., 1994; Li et al., 1994; Loughran et al., 1994; Merlo et al., 1994; Nawroz et al., 1994; van der Reit et al., 1994).

To date only two global analyses of the whole genome have been undertaken with the view to determine the fractional allele loss (FAL) of specific tumours and thus provide information concerning the 'genetic burden' of the disease during its progression as measured by clinicopathological parameters and survival data. This type of analysis has been undertaken in colorectal (Vogelstein et al., 1989) and bladder cancers (Knowles et al., 1994), and provides an indication of interacting genetic mechanisms in the development of these diseases. In addition, the results of such detailed allelotypes may aid the interpretation of carcinogenesis and the development of molecular progression models for specific tumours.

We have undertaken a very comprehensive allelotype of SCCHN using 145 microsatellite markers in order to identify common regions of allelic imbalance and to analyse the

Correspondence: JK Field

Received 13 January 1995: revised 25 May 1995: accepted 16 June 1995. interactions of these regions by calculating the fractional allele loss (FAL) in these tumours.

\section{Materials and methods}

\section{Specimens}

Eighty SCCHN tumour specimens were collected at the Royal Liverpool University Hospital, Department of Otorhinolaryngology and at the Walton Hospital Liverpool, Maxillofacial Unit. Tumour samples obtained from surgical specimens were frozen in liquid nitrogen and stored at $-70^{\circ} \mathrm{C}$. The clinicopathological data on the $52 \mathrm{SCCHN}$ used in fractional allele loss analysis is given in Table I. This group of patients had LOH information on nine or greater (9-39) chromosome arms.

\section{DNA extraction}

All the tumour specimens used for $\mathrm{LOH}$ analysis were microdissected to yield at least $60 \%$ tumour cells before DNA preparation. Genomic DNA was extracted from tumour specimens using the Nucleon II DNA extraction kit (Scotlab) following the manufacturer's instructions. Genomic DNA samples were stored at $4^{\circ} \mathrm{C}$.

\section{$P C R$ and $L O H$ analysis}

Microsatellite repeat primers were obtained from Isogen (The Netherlands). PCR reactions were performed in a $25 \mu \mathrm{l}$ reaction volume and contained $200 \mathrm{ng}$ of genomic DNA, $200 \mu \mathrm{M}$ each dNTP, 5 pmol each of forward and reverse primers, 
Table I Clinicopathological characteristics of the 52 squamous cell carinomas investigated on nine or more chromosomal arms

\begin{tabular}{|c|c|c|c|c|c|c|c|}
\hline $\begin{array}{l}\text { Patient } \\
\text { number }\end{array}$ & History & $T N M$ & Histology & $\begin{array}{l}\text { Nodes at } \\
\text { pathology }\end{array}$ & $\begin{array}{l}\text { Survival } \\
\text { (months) }\end{array}$ & Fate & $\begin{array}{c}F A L^{a} \\
\leqslant \text { Median }\end{array}$ \\
\hline 0128 & PT & TI & Moderate & - ve & 8 & Died of disease & 0.00 \\
\hline 0041 & PU & TII & Well & - ve & 35 & Alive & 0.00 \\
\hline 1052 & PU & TIV & Moderate & - ve & 29 & Alive & 0.00 \\
\hline 0353 & PU & TIV & Moderate & - ve & 12 & Died of disease & 0.05 \\
\hline 1091 & PU & TIII & Well & - ve & 21 & Alive & 0.07 \\
\hline 0302 & PU & TIII & Moderate & - ve & 32 & Alive & 0.10 \\
\hline 0310 & PT & TIV & Moderate & - ve & 5 & Alive & 0.10 \\
\hline 0223 & PT & TI & Poor & - ve & 44 & Alive & 0.11 \\
\hline 0325 & $\mathbf{P U}$ & TIV & Moderate & +ve & 27 & Alive & 0.11 \\
\hline 1086 & $\mathbf{P U}$ & TIV & Poor & + ve & 17 & Alive & 0.11 \\
\hline 0342 & PU & TIII & Moderate & +ve & 18 & Alive & 0.11 \\
\hline 0339 & PT & $\mathbf{T I}$ & Moderate & - ve & 68 & Alive & 0.13 \\
\hline 0359 & PT & TIII & Moderate & - ve & 12 & Alive & 0.13 \\
\hline 0204 & PU & TIII & Moderate & - ve & 21 & Died of disease & 0.14 \\
\hline 1087 & PU & TIV & Moderate & - ve & 22 & Alive & 0.15 \\
\hline 1101 & $\mathbf{P U}$ & TII & Well & - ve & 17 & Alive & 0.15 \\
\hline 0350 & PT & TIII & Moderate & $+v e$ & 11 & Alive & 0.15 \\
\hline 1075 & PU & TII & Moderate & - ve & 23 & Alive & 0.17 \\
\hline 0358 & $\mathbf{P U}$ & TIV & Moderate & + ve & 12 & Alive & 0.17 \\
\hline 0336 & PU & TIII & Well & - ve & 2 & Died of disease & 0.19 \\
\hline 0318 & PT & TIII & Moderate & - ve & 34 & Alive & 0.20 \\
\hline 0340 & PT & TIII & Moderate & - ve & 10 & Alive & 0.20 \\
\hline 0361 & PU & TII & Moderate & + ve & 8 & Alive & 0.20 \\
\hline 0315 & PU & TIV & Moderate & + ve & 99 & Alive & 0.21 \\
\hline \multirow[t]{2}{*}{1062} & PU & TI & Moderate & No data & 7 & Alive & 0.21 \\
\hline & & & & & & & $>$ Median \\
\hline 0215 & $\mathbf{P U}$ & TI & Well & - ve & 36 & Alive & 0.22 \\
\hline 0347 & PT & TIII & Moderate & - ve & 48 & Alive & 0.22 \\
\hline 1164 & PT & TIV & Poor & - ve & 21 & Died of disease & 0.22 \\
\hline 0305 & PU & TIV & Moderate & $+\mathrm{ve}$ & 13 & Died of disease & 0.23 \\
\hline 0225 & PT & TIII & Moderate & - ve & 87 & Died of disease & 0.23 \\
\hline 0228 & PT & TIV & Poor & No data & 56 & Alive & 0.24 \\
\hline 0202 & PT & & Moderate & $+\mathrm{ve}$ & 74 & Alive & 0.28 \\
\hline 0224 & PU & TIII & Moderate & + ve & 20 & Alive & 0.30 \\
\hline 0327 & PU & TIV & Moderate & $+\mathrm{ve}$ & 25 & Alive & 0.30 \\
\hline 0313 & PU & TIV & Moderate & + ve & 8 & Alive & 0.31 \\
\hline 0346 & PU & TIV & Moderate & + ve & 17 & Died of disease & 0.33 \\
\hline 0360 & PU & TIV & Moderate & $+\mathrm{ve}$ & 9 & DOC & 0.33 \\
\hline 1084 & PU & TII & Well & - ve & 9 & Died of disease & 0.33 \\
\hline 0352 & PU & TIV & Moderate & + ve & 11 & Alive & 0.33 \\
\hline 0192 & PU & TIV & Poor & $+\mathrm{ve}$ & 14 & Died of disease & 0.35 \\
\hline 0351 & PU & TIV & Moderate & - ve & 11 & Alive & 0.35 \\
\hline 0348 & PT & TIII & Not defined & +ve & 15 & Alive & 0.35 \\
\hline 0314 & PU & TIV & Moderate & $+v e$ & 8 & Died of disease & 0.36 \\
\hline 0343 & PU & TIV & Moderate & + ve & 19 & Alive & 0.38 \\
\hline 0218 & PU & TIV & Poor & + ve & 5 & Died of disease & 0.41 \\
\hline 0335 & PT & TI & Moderate & + ve & 18 & Alive & 0.44 \\
\hline 0341 & PU & TIII & Moderate & + ve & 0 & Died of disease & 0.45 \\
\hline 0329 & PU & TIV & Moderate & $+v e$ & 7 & Alive & 0.46 \\
\hline 0338 & $\mathrm{PU}$ & TIV & Moderate & - ve & 20 & Alive & 0.47 \\
\hline 0184 & PU & TIII & Poor & + ve & 16 & Died of disease & 0.50 \\
\hline 0324 & PU & TIV & Moderate & + ve & 12 & Alive & 0.56 \\
\hline 0078 & PT & TIII & Poor & - ve & 22 & Died of disease & 0.80 \\
\hline
\end{tabular}

PU, previously untreated; PT, previously treated; DOC, died of other causes. ${ }^{2} \mathrm{FAL}$, fractional allele loss (number of chromosome arms lost divided by the number of chromosome arms examined). Median value of FAL in this group of SCCHN was 0.22 .

0.5 units of Taq polymerase (Advanced Biotechnologies) and $2.5 \mu l 10 \times$ buffer [ $670 \mathrm{mM}$ Tris- $\mathrm{HCl}, \mathrm{pH} 8.5 ; 166 \mathrm{mM}$ ammonium sulphate; $67 \mathrm{mM}$ magnesium chloride; $1.7 \mathrm{mg} \mathrm{ml}^{-1}$ bovine serum albumin (BSA); $100 \mu \mathrm{M} \beta$-mercaptoethanol; $1 \%$ $(w / v)$ Triton $X-100]$. The reactions were denatured for $5 \mathrm{~min}$ at $95^{\circ} \mathrm{C}$ then the DNA was amplified for 30 cycles of $95^{\circ} \mathrm{C}$ for $30 \mathrm{~s}, 57^{\circ} \mathrm{C}$ for $30 \mathrm{~s}$ and $72^{\circ} \mathrm{C}$ for $30 \mathrm{~s}$. Aliquots of $10 \mu \mathrm{l}$ of the PCR product were electrophoresed for $10 \mathrm{~h}$ on a $10 \%$ non-denaturing polyacrylamide gel at $250 \mathrm{~V}$ and visualised by silver staining.

LOH or allelic imbalance was scored by direct visual comparison of the allelic ratios of the normal and tumour specimens. Examples of heterozygous, homozygous and $\mathrm{LOH}$ in tumour/normal SCCHN specimens are given in Figure 1. Complete loss or reduced intensity of one allele in the tumour was considered as LOH. In the cases where there was only a reduced intensity of one allele this was considered to be due to contamination of tumour tissue by normal stroma. It has been previously noted by Ah-Set et al. (1994) that the PCR techniques used by a number of authors in similar studies cannot readily distinguish between allelic duplication or low-level amplification leading to loss of heterozygosity. This caveat has to be taken into consideration when interpreting these results and thus LOH may not necessarily be indicative of the presence of a tumour-suppressor gene.

\section{Statistical analysis}

Quantitative data were analysed by $\chi^{2}$ or Fisher's exact test where appropriate. Survival curves were drawn using the Kaplan-Meier (1958) product limit estimate. Differences between survival times were analysed by the log-rank method (Peto et al., 1976). 
a

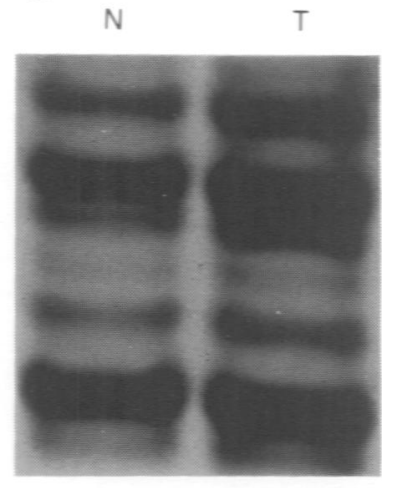

b

N $\quad T$

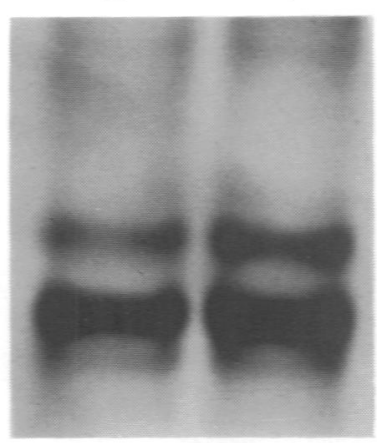

C

N

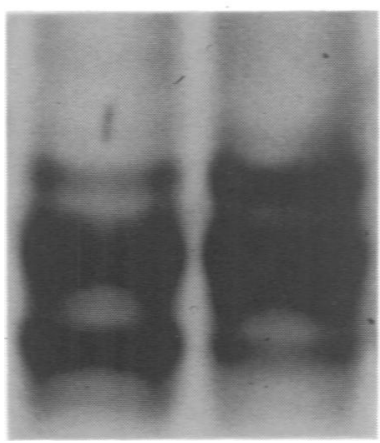

Figure 1 Representative figure of allelic imbalance (loss of heterozygosity). (a) Retention of heterozygosity. (b) Homozygosity. (c) Allelic imbalance (loss of heterozygosity), loss of the upper band in the tumour specimen. $N$, normal: $T$, tumour DNA. 'Stutter' or 'shadow bands' may be seen in both the normal and tumour lanes.

\section{Results}

A total of 80 SCCHN tumours were investigated for LOH using 145 microsatellite markers and loss on individual chromosome arms was calculated using the total data set (Table II). A total of 1092 chromosomal arms were analysed, of which $956(88 \%)$ were informative. The most frequent losses were found on chromosome arms $3 p, 9 p, 17 p$ and $18 q$. with over $45 \% \mathrm{LOH}$; losses on 1p, 1q, $2 \mathrm{p}, 5 \mathrm{q}, 6 \mathrm{p}, 6 \mathrm{q}, 8 \mathrm{p}, 8 \mathrm{q}$, $9 q, 11 q, 13 q, 17 q$ and $19 q$ were found in more than $20 \%$ of cancers (Figure 2).

\section{Loss of heterozygosity at specific loci}

The highest incidence of $\mathrm{LOH}$ was found on chromosome 9p (24/39) with a $62 \%$ loss and this allelic imbalance was especially concentrated between the D9S161 (9p21) and D9S156 (9p23-9p22) informative markers in this region (JK Field et al., in preparation), which agrees with the observations of van der Riet et al. (1994).
The second highest percentage of allelic imbalance $(52 \%)$ was found on chromosome arm $3 p$ from 61 informative tumours. Using 18 markers we found the greatest loss in the $3 \mathrm{p} 24-\mathrm{p} 25$ and $3 \mathrm{p} 13$ regions and a very small incidence of LOH at the $3 \mathrm{p} 21$ site, including the D3S1217 marker (3p21) which had a LOH of only $10 \%$ (Field et al.. 1994; JK Field et al., unpublished).

Chromosome $17 \mathrm{p}$ revealed an $\mathrm{LOH}$ of $50 \%$ with the highest loss at the CHRNB1 locus (17p12-p11.1). Furthermore, as previously reported by Adamson et al. (1994), LOH at this locus was found in $77 \%$ of the hypopharyngeal carcinomas studied.

Markers on 18q showed an overall LOH of 49\% (20 41). however the main area of loss was not associated with the DCC marker at $18 \mathrm{q} 21.1$ but was found at D18S35 (18q21.1-q21.3) (33\%) (Rowley et al., 1995).

Significant losses, $29 \%$ (13 45), were also found on chromosome arm 5q. eight markers were used, including D5S346 (5q21-q22) in the APC MCC region which showed $35 \%$ LOH $(926)$. Six patients in this group of tumours showed loss only in this region. which was bounded in each case by informative heterozygous markers centromeric and telomeric of DSS346. thereby indicating that this region plays an important role in some SCCHN.

LOH on $8 \mathrm{p}$ has been demonstrated in a range of tumours with the 8p21.3-p11.22 region being of most interest. Our investigations using five microsatellite markers on $8 p$ have shown $35 \%(1440) \mathrm{LOH}$. which appears to be concentrated particularly at the $D 8 S 87(8 \mathrm{pl})$ and $A N K 1(8 \mathrm{p} 21.1-\mathrm{pl} 1.2)$ loci (29\% and $20 \% \mathrm{LOH}$ respectively). However, when the results of these two markers were combined. $37 \%$ (13 35) LOH was demonstrated (Kiaris et al., 1994).

LOH has also been observed on chromosome arm $1 \mathrm{p}$ in a range of tumours, with the $1 \mathrm{p} 31.2-\mathrm{p} 21.3$ region indicating that this may be a further target region in $S C C H N$. The cumulative loss of two markers in this region, D1S159 (1p22.1-p21) and D1S167 (1p22-p21), was 24\% (14 46).

Chromosome 11 contains an amplicon region at $11 \mathrm{q} 13$ which includes the int-2, cyclin $D$ and $E M S-1$ genes. We have found $23 \%$ LOH $(939)$ on the $11 \mathrm{q}$ arm and $\mathrm{LOH}$ at the int-2 locus was $17 \%\left(\begin{array}{ll}3 & 18\end{array}\right)$

In this data set, whole chromosome loss was seen only on chromosome 17 and in four tumours: 78, 192, 225 and 335 ( $11 \%$ of cases). All of these chromosome arms showing LOH at greater than $20 \%$ (3p, 17p, 9p, 18q, 5q, 8p, 1p and 11q) have been previously shown to contain either known or putative tumour-suppressor genes. However, there are other arms in this study with greater than $20 \% \mathrm{LOH}(1 \mathrm{q}, 2 \mathrm{p}, 6 \mathrm{p}$, $6 q, 8 q, 13 q, 17 q$ and $19 q)$ and these may also be target regions involved in the development of SCCHN.

\section{LOH data analysed against a range of clinicopathological parameters}

LOH data for each chromosomal arm were analysed against a range of clinicopathological parameters, including site of the tumour, histology, TNM staging, nodes at pathology and survival (Table I). These calculations were undertaken on the whole data set of 80 tumours (previously untreated and previously treated) and on the two subgroups separately. In the whole data set $(80 \mathrm{SCCHN})$, correlations were found between nodes at pathology and LOH on $9 q(P=0.020)$ and between histopathological grading and LOH on $12 \mathrm{q}$ $(P=0.022)$ and on $13 q \quad(P=0.012)$. In the group of previously untreated tumours, a correlation was found between site and LOH on $3 p(P=0.032)$ and $8 \mathrm{p}(P=0.029)$, while TNM staging correlated with LOH on 3p $(P=0.019)$ and $17 \mathrm{p}(P=0.016)$. Only one association was found in the group of previously treated patients, between nodes at pathology and LOH on $11 \mathrm{p}(P=0.045)$ (Table III).

\section{Fractional allele loss}

LOH data from all 39 chromosome arms were assessed separately for the 52 SCCHN tumours which had inform- 
Table II Loss of heterozygosity analysis of 145 microsatellite markers in SCCHN on 39 chromosomal arms

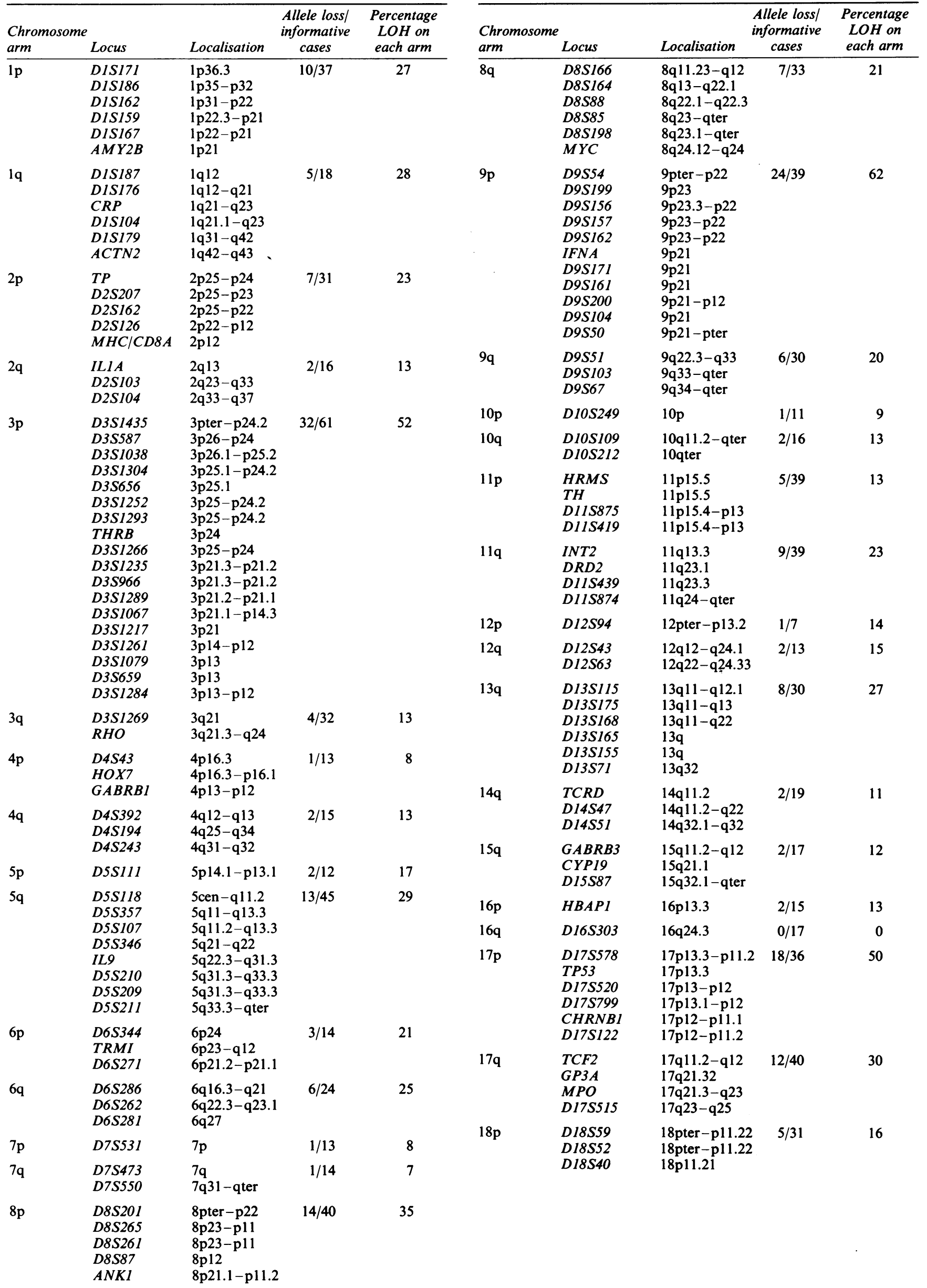


Table II-continased

\begin{tabular}{|c|c|c|c|c|}
\hline $\begin{array}{l}\text { Chromosome } \\
\text { arm }\end{array}$ & Locus & Localisation & $\begin{array}{l}\text { Allele loss } \\
\text { informative } \\
\text { cases }\end{array}$ & $\begin{array}{l}\text { Percentage } \\
\text { LOH on } \\
\text { each arm }\end{array}$ \\
\hline $18 \mathrm{q}$ & $\begin{array}{l}D 18 S 34 \\
D 18 S 35 \\
D C C \\
D 18 S 38 \\
D 18 S 42 \\
D 18 S 43 \\
M B P \\
D 18 S 70\end{array}$ & $\begin{array}{l}18 \mathrm{q} 12.2-\mathrm{q} 12.3 \\
18 \mathrm{q} 21.1-\mathrm{q} 21.3 \\
18 \mathrm{q} 21.1 \\
18 \mathrm{q} 21.31 \\
18 \mathrm{q} 22.1 \\
18 \mathrm{q} 22.3-\mathrm{q} 23 \\
18 \mathrm{q} 23 \\
18 \mathrm{q} 23-\mathrm{qter}\end{array}$ & $20 / 41$ & 49 \\
\hline $19 p$ & D19S20 & 19p13.3 & $0 / 9$ & 0 \\
\hline $19 q$ & $\begin{array}{l}\text { D19S49 } \\
\text { D19S180 }\end{array}$ & $\begin{array}{l}19 \mathrm{q} 12-\mathrm{q} 13.1 \\
19 \mathrm{q} 13.4\end{array}$ & $5: 17$ & 29 \\
\hline $20 p$ & $D 20 S 57$ & $20 \mathrm{pl} 13$ & 014 & 0 \\
\hline $20 q$ & $D 20 S 120$ & $20 q$ & $1 / 11$ & 9 \\
\hline 219 & $D 21 S 156$ & $21 \mathrm{q} 22.3$ & $1 / 12$ & 8 \\
\hline $22 q$ & $I L 2 R B$ & $22 \mathrm{q} 11.2-\mathrm{q} 12$ & 015 & 0 \\
\hline
\end{tabular}

ation on nine or greater (range 9-39) chromosome arms. This subgroup of 52 tumours was composed of 36 previously untreated tumours and 16 previously treated tumours. Allelotypes derived from 145 microsatellite markers are presented diagrammatically in Figure 3. The fractional allele loss (FAL) in a tumour is defined as the number of chromosomal arms on which allelic imbalance was observed divided by the number of chromosomal arms for which markers were informative in the patient's normal cells (Vogelstein et al., 1989). The FAL values for this group of 52 SCCHN showed a median value of 0.22 and a mean of 0.25 (range $0.0-0.80$ ).
FAL values were assessed against the clinicopathological data (tumour site, tumour grade, TNM staging, nodes at pathology) by dividing the tumours into those with FAL $>$ median value and those with $F A L<$ median value. A positive correlation was found between FAL and nodes at pathology $(P=0.01)$ and between FAL and tumour grade $(P=0.06)$ (Table IV). This demonstrates that advanced tumours with lymph nodal metastasis often had $\mathrm{LOH}$ at multiple sites. No correlation was found between FAL and the patient's history of smoking or drinking (Table V).

The FAL data was also investigated for a possible association with clinical outcome using the log-rank analysis. It was found that a FAL $>$ median value correlated with poor survival $(P<0.032)$, and furthermore that a FAL $>$ median value also correlated with a poor survival in the previously untreated patients $(P<0.019)$ when analysed separately. In order to analyse a homogeneous group of patients for FAL with clinical outcome, we calculated the log rank on the subset of 40 advanced tumours (TNM III and IV) and this also demonstrated a correlation between FAL and prognosis $(P<0.05)$.

\section{Discussion}

In this detailed allelotype of SCCHN we have demonstrated a complex set of genetic alterations, a finding that has also been described in a range of human cancers (Vogelstein et al., 1989; Sato et al., 1990, 1991; Fujimori et al., 1991; Morita et al., 1991; Tsuchiya et al., 1992; Yamaguchi et al., 1992; Aoki et al., 1994; Fujino et al., 1994; Knowles et al., 1994). The highest LOH was found on the chromosome arms $3 p, 9 p, 17 p$ and $18 q$ which is in general agreement with previous studies on SCCHN (Ah-See et al., 1994; Nawroz et al., 1994). Table VI provides an overview of the results

Table III LOH data analysed against a range of clinicopathological parameters

\begin{tabular}{lccccc}
\hline & $\begin{array}{c}\text { Chromosome } \\
\text { arm }\end{array}$ & Site & Nodes & TNM & Pathology \\
\hline Total data & & & & & \\
$(n=80)$ & $9 \mathrm{q}$ & NS & 0.020 & NS & NS \\
previously & $12 \mathrm{q}$ & NS & NS & NS & 0.022 \\
treated untreated & $13 \mathrm{q}$ & NS & NS & NS & 0.012 \\
Previously & $3 \mathrm{p}$ & 0.032 & NS & 0.019 & NS \\
$\quad$ untreated & $8 \mathrm{p}$ & 0.029 & NS & NS & NS \\
Previously & $17 \mathrm{p}$ & NS & NS & 0.016 & NS \\
treated & $11 \mathrm{p}$ & NS & 0.045 & NS & NS \\
\hline
\end{tabular}

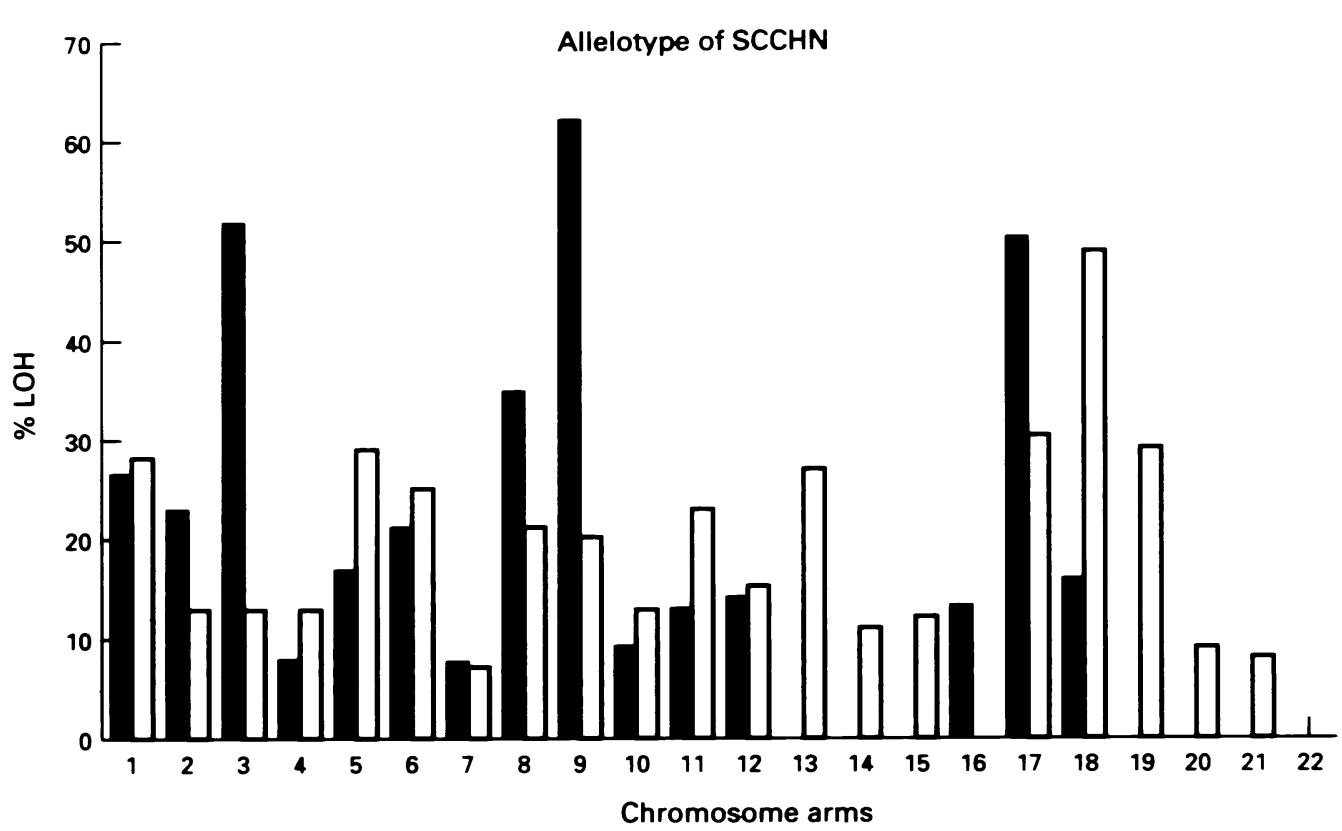

Figure 2 Frequency of allele loss on each chromosome arm in 80 squamous cell carcinomas of the head and neck. $\square, p$ arm; $\square, q$ arm. 


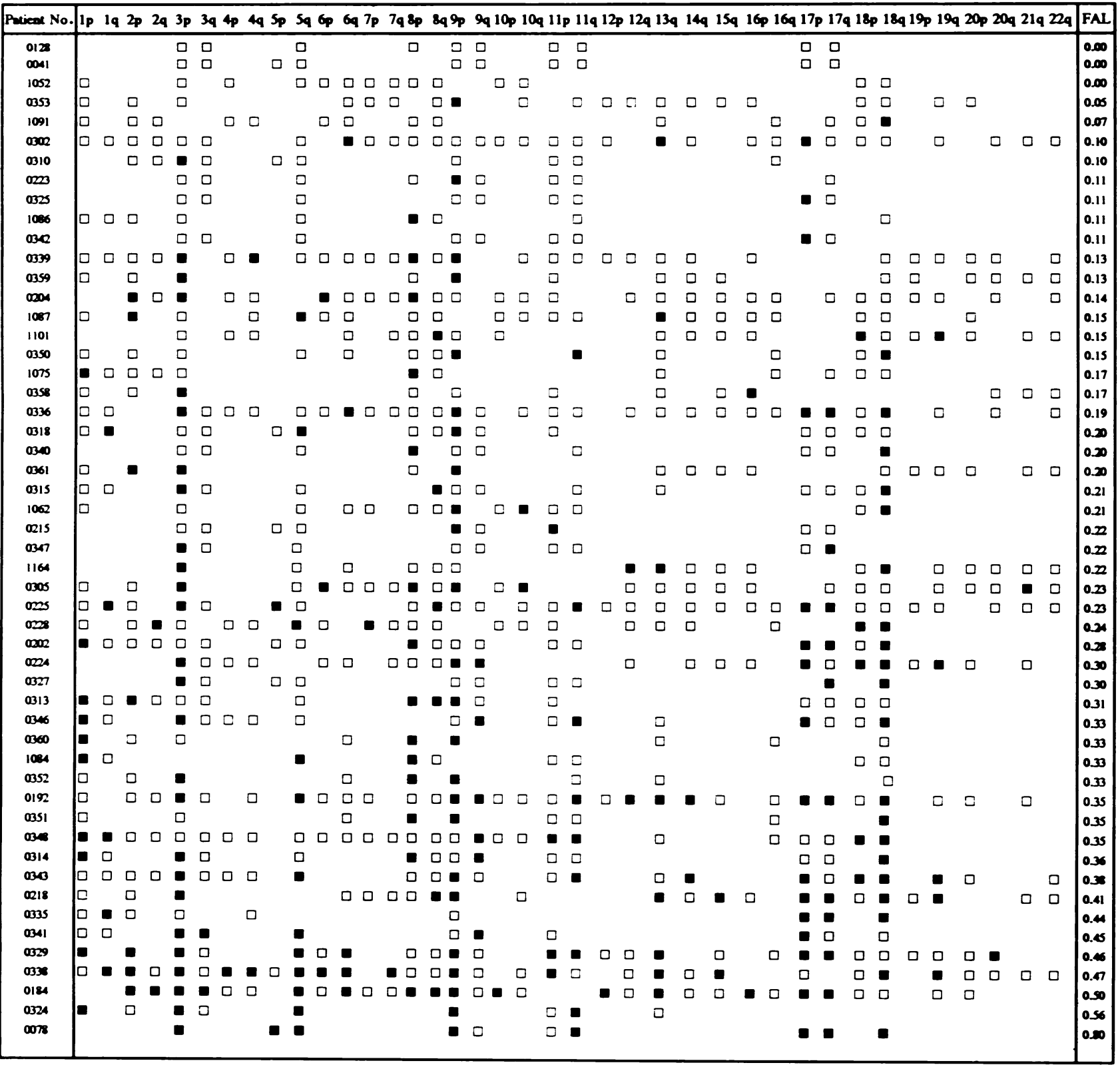

Figure 3 Individual allelotypes for 52 squamous cell carcinomas of the head and neck. These SCCHN tumours were investigated on nine or more informative chromosomal arms (range 9-39). The FAL (fractional allele loss) data has been given for each tumour specimen (range $0.0-0.80$ ). $\mathrm{Q}, \mathrm{LOH} ; \mathrm{\square}$, retention of heterozygosity; chromosome arms which were uninformative or not done are not shown. Each square represents the summation of the LOH results on a single chromosome arm using all of the informative markers, i.e. if there was allelic imbalance for any one of the markers tested for that specific chromosomal arm, then it is indicated as a filled square.

undertaken in this study in comparison with those in the two other allelotypes undertaken on SCCHN tumours. Both of the previous studies used about one-third of the number of markers used in this analysis: 58 markers (Nawroz et al., 1994) and 52 markers (Ah-See et al., 1994) respectively. Similar LOH values have been found at $3 p, 5 q$, and $9 q$ between Ah-See et al. (1994) and these data ( $\pm 15 \%)$, in the cases where the results may be compared. Also, similar LOH findings may be seen between Nawroz et al. (1994) and this data set for chromosome arms, 1p, 1q, 3p, 5q, 8p, 8q, 9p, 9q, $11 p, 17 p, 17 q$ and $19 q( \pm 15 \%)$. However, a number of differences $(> \pm 20 \%)$ do exist between the previous reports and our results on $9 p, 11 q, 13 q$ and $18 q$. The percentage LOH for $11 \mathrm{q}$ varies from $23 \%, 45 \%$ to $61 \%$ in the three studies (Ah-See et al., 1994; Nawroz et al., 1994; these data respectively), however the two previous studies only used two markers on this chromosome arm. The data on $18 \mathrm{q}$ from Nawroz et al. (1994) based on one marker give an LOH of $29 \%$, whereas eight markers have been used in this study, demonstrating an $\mathrm{LOH}$ of $49 \%$. This analysis demonstrates
Table IV Association between FAL and nodes at pathology and tumour grade

\begin{tabular}{|c|c|c|c|}
\hline \multirow[b]{2}{*}{ Clinical parameter } & \multicolumn{2}{|c|}{$F A L$} & \multirow[b]{2}{*}{$\mathbf{P}$} \\
\hline & $\leqslant$ Median & $\begin{array}{c}>\text { Median } \\
\text { value }\end{array}$ & \\
\hline \multicolumn{4}{|l|}{ Nodes at pathology } \\
\hline No nodes & 17 & 8 & \\
\hline Positive nodes & 7 & 18 & 0.01 \\
\hline \multicolumn{4}{|l|}{ TNM status } \\
\hline TNM I and II & 8 & 3 & \\
\hline TNM III and IV & 16 & 23 & 0.06 \\
\hline
\end{tabular}

${ }^{2}$ Fisher's exact $t$-test.

that the results of the three allelotypes on SCCHN agree in general, however when only a limited number of markers are chosen per arm there is a very high probability that a target region may be missed.

The results from this study provide further confirmation of 
Table V Association between FAL and a history of smoking and drinking in patients with SCCHN

\begin{tabular}{|c|c|c|c|c|c|c|c|c|c|c|}
\hline & $\begin{array}{c}\text { Non- } \\
\text { smoker }\end{array}$ & $\begin{array}{l}\text { Moderate } \\
\text { smoker } \\
<20 \text { per day }\end{array}$ & $\begin{array}{c}\text { Heavy } \\
\text { smoker } \\
>20 \text { per day }\end{array}$ & $\begin{array}{l}\text { Stopped } \\
\text { smoking }\end{array}$ & $\mathbf{P}^{a}$ & $\begin{array}{c}\text { Non- } \\
\text { drinker }\end{array}$ & $\begin{array}{l}\text { Moderate } \\
<21 \text { units } \\
\text { per week }\end{array}$ & $\begin{array}{c}\text { Heavy } \\
>21 \text { units } \\
\text { per week }\end{array}$ & $\begin{array}{l}\text { Stopped } \\
\text { drinking }\end{array}$ & $\mathbf{P}^{a}$ \\
\hline FAL $\leqslant$ median & 5 & 5 & 8 & 2 & & 6 & 4 & 8 & 1 & \\
\hline FAL $>$ median & 5 & 3 & 9 & 4 & 0.7 & 4 & 6 & 10 & 1 & 0.9 \\
\hline
\end{tabular}

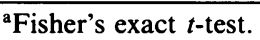

Table VI Comparison of LOH from three allelotypes of SCCHN

\begin{tabular}{lcccccc}
\hline $\begin{array}{l}\text { Chromosome } \\
\text { arm }\end{array}$ & $\begin{array}{c}\text { Ah-See et al. (1994) } \\
\text { No. of } \\
\text { markers }\end{array}$ & LOH (\%) & $\begin{array}{c}\text { Nawroz et al. (1994) } \\
\text { No. of } \\
\text { markers }\end{array}$ & LOH (\%) & $\begin{array}{c}\text { This study } \\
\text { No. of } \\
\text { markers }\end{array}$ & LOH (\%) \\
\hline $1 \mathrm{p}$ & 1 & $14^{\mathrm{a}}$ & 2 & 30 & 6 & 27 \\
$1 \mathrm{q}$ & 2 & $0^{\mathrm{a}}$ & 1 & 23 & 6 & 28 \\
$3 \mathrm{p}$ & 3 & 44 & 2 & 67 & 18 & 52 \\
$5 \mathrm{q}$ & 4 & 43 & 1 & 25 & 8 & 29 \\
$8 \mathrm{p}$ & 1 & $10^{\mathrm{a}}$ & 1 & 40 & 5 & 35 \\
$8 \mathrm{q}$ & 1 & $7^{\mathrm{a}}$ & 2 & 38 & 6 & 21 \\
$9 \mathrm{p}$ & 1 & $24^{\mathrm{a}}$ & 3 & 72 & 11 & 62 \\
$9 \mathrm{q}$ & 2 & 35 & 2 & 18 & 3 & 20 \\
$11 \mathrm{p}$ & 1 & $5^{\mathrm{a}}$ & 2 & 17 & 4 & 13 \\
$11 \mathrm{q}$ & 2 & 45 & 2 & 61 & 4 & 23 \\
$13 \mathrm{q}$ & 1 & $0^{\mathrm{a}}$ & 2 & 54 & 6 & 27 \\
$17 \mathrm{p}$ & 2 & 31 & 3 & 52 & 6 & 50 \\
$17 \mathrm{q}$ & 1 & $19^{\mathrm{a}}$ & 2 & 31 & 4 & 30 \\
$18 \mathrm{q}$ & 1 & $0^{\mathrm{a}}$ & 2 & 29 & 2 & 49 \\
$19 \mathrm{q}$ & 1 & $0^{\mathrm{a}}$ & 2 & 40 & 2 & 29 \\
\hline
\end{tabular}

${ }^{a}$ Data taken from Figure 2, Ah-See et al. (1994).

target regions in SCCHN containing putative tumoursuppressor genes on $3 p$ and $9 p$ as well as a high LOH associated with the $\mathrm{p} 53$ gene. In addition, this analysis provides evidence for regions of minimal loss in SCCHN on $1 \mathrm{p}$, 8p, 17p and 18q (Adamson et al., 1994; Kiaris et al., 1994; Rowley et al., 1995; K Taylor et al., in preparation). The 1p minimal area of loss has been located at $1 \mathrm{p} 31.2-\mathrm{p} 21.3$, a region previously shown by karyotype analysis to contain cytogenetic abnormalities (Jin et al., 1990, 1993; Owens et al., 1992). A minimal area of loss has also been identified on $8 p$ between $8 \mathrm{p} 12$ and $8 \mathrm{p} 21.2-\mathrm{p} 11$ in this series of tumours, a region considered to contain a candidate tumour-suppressor gene in colonic and hepatocellular carcinomas (Fujiwara et al., 1993; Cunningham et al., 1994). We have recently described a novel region on $17 p$ distinct from TP53, at CHRNB1 (17q12-p11.1), in SCCHN which has a particularly high loss in hypopharyngeal carcinomas (77\%) (Adamson et al., 1994). Furthermore the detailed analysis of $18 \mathrm{q}$ has allowed us to identify a region at $18 \mathrm{q} 21.1-\mathrm{q} 21.3$ as a target region in SCCHN, which does not appear to be the DCC (deleted in colon cancer) gene as we found a very low LOH at the $D C C$ locus. Thus it may be argued that there is a second tumour-suppressor gene in this region on $18 \mathrm{q}$ that is involved in SCCHN.

Two further chromosomal regions considered to contain tumour-suppressor genes in other neoplasms have not been shown to play an important role in SCCHN. Even though there is frequent LOH on 13q (Yoo et al., 1994) there does not appear to be inactivation of the retinoblastoma gene, and it has been argued by these authors that there may be another tumour-suppressor locus at 13q14. Also, the $A P C /$ $M C C$ locus on $5 \mathrm{q}$, which has been demonstrated to be involved in colorectal carcinomas (Kinzler et al., 1991) and has previously been shown to have a high LOH in SCCHN (Ah-See et al., 1994), may not in fact be the target locus, as mutations in the $A P C$ gene have rarely been found in oral cancers (Uzawa et al., 1994).

Analysis of $\mathrm{LOH}$ for each chromosomal arm was assessed against a range of clinicopathological parameters (Table III). In particular, a correlation was found between site and LOH on $3 p$ and $8 p$, while TNM staging correlated with LOH on $3 p$ and $17 p$ in previously untreated tumours. Also, in the group of previously untreated and previously treated tumours a correlation was found between LOH on $9 q$ and positive nodes at pathology, and histological grading correlated with $\mathrm{LOH}$ on $12 \mathrm{q}$ and 13q. In a detailed study undertaken by Lee et al. (1994), on chromosome 13 (using 13 markers), a correlation was found between $\mathrm{LOH}$ on 13q and lymph node metastasis. Moreover, these authors reported that they found similar LOH in a subset of the tumours in the adjacent non-malignant mucosa. However, no correlation between $\mathrm{LOH}$ at $13 \mathrm{q}$ and lymph node metastasis was observed in the study described here.

The phenomenon of microsatellite instability (MI) (Mao et al., 1994; Field et al., 1995) has been demonstrated in some of these SCCHN tumours, but no correlation was found between $\mathrm{MI}$ and $\mathrm{LOH}$ on any chromosome arm in this study. MI is therefore considered to be a separate pathogenic mechanism in the development of SCCHN.

The fractional allele loss (FAL) data were assessed for 52 tumours on which there was $\mathrm{LOH}$ information on nine or more chromosome arms. In this group we found a median FAL value of 0.22 , mean of 0.25 (range $0.0-0.80$ ). This demonstrates that alleles were lost on average from $25 \%$ of the chromosome arms in these tumours; a figure that is comparable with that obtained in non-small-cell carcinoma and colorectal carcinomas $(0.2)$, bladder and breast carcinomas (0.11) and osteosarcarcinomas (0.32) (Sato et al., 1990, 1991; Morita et al., 1991; Tsuchiya et al., 1992; Knowles et al., 1994). The FAL values were compared with the clinicopathological data based on FAL $\leqslant$ median value and FAL $>$ median value. A correlation was found between FAL and positive nodes at pathology $(P=0.01)$, a clinical parameter considered to be the most useful prognostic indicator in head and neck cancer. No statistical correlation was found between FAL and site, TNM staging or histological differentiation. A history of smoking and drinking has been correlated with overexpression and mutations in the p53 gene (Field et al., 1991, 1994; Field, 1992; Brennan et al., 1995), but no correlation has been found between these carcinogens and FAL in this analysis. In colorectal carcinomas, Vogelstein et al. (1989) found no correlation between FAL and Dukes' classification or tumour size, whereas in the allotype on bladder carcinomas, a correlation 
was found between FAL and tumour grade but not with the stage of the disease (Knowles et al., 1994). Thus, all three analyses demonstrate no correlation between FAL and tumour stage.

We have demonstrated that a FAL $>$ median value correlated with a poor prognosis in all 52 patients analysed $(P<0.032)$ and also in the subset of previously untreated patients $(P<0.019)$ calculated by the log-rank method Vogelstein et al. (1989) also showed a relationship between FAL and prognosis for colon cancers with a similar number

\section{References}

ADAMSON R JONES AS AND FIELD JK (1994), Loss of heterozygosity studies on chromosome 17 in head and neck cancer using microsatellite markers. Oncogene, 9, 2077-2082.

AH-SEE KW. COOKE TG. PICKFORD IR. SOUTAR D AND BALMAIN A. (1994). An allelotype of squamous carcinoma of the head and neck using microsatellite markers. Cancer Res., 54, 1617-1621.

AOKI T. MORI T. DU XQ. NISIHIRA T. MATSUBARA T AND NAKAMURA Y. (1994). Allelotype study of esophageal carcinoma. Genes Chrom. Cancer, 10, 177-182.

BRENNAN JA. BOYLE JO. KOCH WM, GOODMAN SN, HRUBAN RH. EBY YJ. COUCH MJ. FORASTIERE AA AND SIDRANSKY D. (1995). Association between cigarette smoking and mutation of the p53 gene in squamous cell carcinoma of the head and neck Nen: Engl. J. Med., 332, 712-717.

CUNNINGHAM C. DUNLOP MG. WYLLIE AH AND BIRD CC. (1993) Deletion mapping in colorectal cancer of a putative tumour suppressor gene in 8p22-p21.3. Oncogene, 8, 1391-1396.

FIELD JK. (1992). Oncogenes and tumour-suppressor genes in squamous cell carcinoma of the head and neck. Eur. J. Cancer Oral Oncol., 28B, 67-76.

FIELD JK. SPANDIDOS DA. STELL PM. VAUGHAN ED. EVAN GI AND MOORE JP. (1989). Elevated expression of the c-myc oncoprotein correlates with poor prognosis in head and neck squamous cell carcinoma. Oncogene, 4, 1463-1468.

FIELD JK. SPANDIDOS DA. MALLIRI A. YIAGNISIS M. GOSNEY JR AND STELL PM. (1991). Elevated p53 expression correlates with a history of heavy smoking in squamous cell carcinoma of the head and neck. Br. J. Cancer, 64, 573-577.

FIELD JK. TSIRIYOTIS C. HOWARD P AND JONES AS. (1994). Allele loss on chromosome 3 in squamous cell carcinoma of the head and neck correlates with poor clinical prognostic indicators. Int. J. Oncol. . 4, 543-549.

FIELD JK. KIARIS H. HOWARD P. VAUGHAN ED SPANDIDOS DA AND JONES AS. (1995). Microsatellite instability in squamous cell carcinoma of the head and neck. Br. J. Cancer, 71, 1065-1069.

FUJIMORI M. TOKINO T, HINO O, KITAGAWA T, IMAMURA T, OKAMOTO E. MITSUNOBU M, ISHIKAWA T, NAKAGAMA $H$. HARADA H. YAGURA M. MATSUBARA K AND NAKAMURA Y (1991). Allelotype study of primary hepatocellular carcinoma. Cancer Res., 51, 89-93.

FUIINO T, RISINGER JI, COLLINS NK, LIU FS, NISHII H, TAKAHASHI H, WESTPHAL EM. BARRETT JC. SASAKI H. KOHLER MF. BERCHUCK A AND BOYD J. (1994). Allelotype of endometrial carcinoma. Cancer Res., 54, 4294-4298.

FUJIWARA Y, EMI M. OHATA H, KATO Y, NAKAJIMA T, MORI T AND NAKAMURA Y. (1993). Evidence for the presence of two tumour suppressor genes on chromosome $8 p$ for colorectal carcinoma. Cancer Res., 53, 1172-1174.

JIN Y. HEIM S. MANDAHL N, BIÖRKLUND A, WENNERBERG AND MITELMAN F. (1990). Diverse chromosomal aberrations in carcinomas of the oral cavity. Genes Chrom. Cancer, 1, 209-215.

JIN Y. MERTENS F. MANDAHL N. HEIM S OLEGARD C WENNERBERG J. BIORKLUND A AND MITELMAN F. (1993). Chromosome abnormalities in eighty-three head and neck squamous cell carcinomas: influence of culture conditions on karyotypic pattern. Cancer Res., 53, 2140-2146.

KAPLAN EL AND MEIER P. (1958). Nonparametric estimation from complete observation. J. Am. Stat. Assoc., 53, 457-481.

KIARIS H, JONES AS, SPANDIDOS DA. VAUGHAN ED AND FIELD JK. (1994). Loss of heterozygosity on chromosome 8 in squamous cell carcinoma of the head and neck. Int. J. Oncol. 51, 579-582.

KINZLER KW. NILBERT MC, SU L-K. VOGELSTEIN B. BRYAN TM. LEVY DB. SMITH KJ. PREISINGER AC. HEDGE P. MCKECHNIE D. FINNIEAR R, MARKHAM A. GROFFEN J, BOGUSKI MS, ALT SCHUL SF, HORII A. ANDO H, MIYOSHI Y, MIKI Y, NISHISHO I AND NAKAMURA Y. (1991). Identification of FAP locus genes from chromosome 5q21. Science, 253, 661-665. and distribution of patients $(P<0.01)$ using Fisher's exact test. Thus the argument originally proposed by Vogelstein $e t$ al. (1989) that recognition of accumulated genetic damage, as provided by the allelotype, provides a useful molecular indicator of the tumour behaviour is supported by the findings of this study.

\section{Actrowledgenents}

This research was supported by a grant from the North West Cancer Research Fund UK.

KNOWLES MA. ELDER PA. WILLIAMSON M. CAIRNS JP. SHAW ME AND LAW MG. (1994). Allelotype of human bladder cancer. Cancer Res., 54, 531-538.

LASKO D. CAVENEE W AND NORDENSKJOLD M. (1991). Loss of constitutional heterozygosity in human cancer. Annu. Rev. Genet.. 25, $281-314$

LATIF F. FIVASH M. GLENN G. TORY K. ORCLTT ML. HAMPSCH K. DELISIO J. LERMAN M. COWAN J. BECKETT M AND WEICHSELBAUM R. (1992). Chromosome 3p deletions in head and neck carcinomas: statistical ascertainment of allelic loss. Cancer Res.. 52, $1451-1456$

LEE NK. YE Y-W. LI X. SCHWEITZER C AND NISEN PD. (1994). Allelic loss on chromosome 13 can precede histological changes in head and neck cancer. Int. J. Oncol.. 5, 205-210.

LI XH. LEE NK. YE YW. WABER PG. SCHWEITZER C. CHENG QC AND NISEN PD. (1994). Allelic loss at chromosomes 3p. 8p, 13q. and $17 p$ associated with poor-prognosis in head and neck cancer. J. Natl Cancer Inst., 86, 1524-1529.

LOUGHRAN O. EDINGTON KG, BERRY LJ. CLARKE LJ AND PARKINSON EK. (1994). Loss of heterozygosity of chromosome 9p21 is associated with the immortal phenotype of neoplastic human head and neck keratinocytes. Cancer Res., 54, 5045-5049.

MAESTRO R. GASPAROTTO D. VUKOSAVLUEVIC T. BARZAN L. SULFARO S AND BOIOCCHI M. (1993). Three discreet regions of deletion at $3 p$ in head and neck cancers. Cancer Res., 53, 5775-5779.

MAO L. LEE DJ, TOCKMAN MS, EROZAN YS, ASKIN F AND SIDRANSKY D. (1994). Microsatellite alterations as clonal markers for the detection of human cancer. Proc. Natl Acad. Sci. USA. 91, $9871-9875$.

MERLO A. GABRIELSON E, ASKIN F AND SIDRANSKY D. (1994). Frequent loss of chromosome-9 in human primary nonsmall cell lung cancer. Cancer Res., 54, 640-642.

MORITA R. ISHIKAWA J. TSUTSUMI M. HIKIJI K. TSUKADA Y. KAMIDONO S. MAEDA S AND NAKAMURA Y. (1991). Allelotype of renal cell carcinoma. Cancer Res., 51, 820-823.

NAWROZ H. VANDERRIET P. HRUBAN RH. KOCH W. RUPPERT JM AND SIDRANSKY D. (1994). Allelotype of head and neck squamous cell carcinoma. Cancer Res., 54, 1152-1155.

OWENS W. FIELD JK. HOWARD T AND STELL PM. (1992). Multiple cytogenetic aberrations in squamous cell carcinoma of the head and neck. Eur. J. Cancer Oral Oncol., 28B, 17-22.

PETO R. PIKE MC. ARMITAGE PE. BRESLOW NE. COX DR. HOWARD SV, MANTEL N. MCPHERSON K. PETO J AND SMITH PG. (1976). Design and analysis of randomised clinical trials requiring prolonged observation of each patient. $\mathrm{Br}$. J. Cancer. 34, $585-612$.

REES M, LEIGH SEA. DELHANTY JDA AND JASS JR. (1989). Chromosome 5 allele loss in familial and sporadic colorectal adenomas. Br. J. Cancer, 59, 361-365.

ROWLEY H, JONES AS AND FIELD JK. (1995). Chromosome 18: a possible site for a tumour suppressor gene deletion in squamous cell carcinoma of the head and neck. Clin. Otolaryngol., 20, 266-271.

SATO T. TANIGAMI A. YAMAKAWA K. AKIYAMA F. KASUMI F. SAKAMOTO G AND NAKAMURA Y. (1990). Allelotype of breast cancer: cumulative allele losses promote tumour progression in primary breast cancer. Cancer Res., 50, 7184-7189.

SATO T, SAITO H. MORITA R. KOI S. LEE JH AND NAKAMURA Y. (1991). Allelotype of human ovarian-cancer. Cancer Res. 51, $5118-5122$.

TSUCHIYA E. NAKAMURA Y. WENG SY. NAKAGAWA K. TSUCHIYA S, SUGAND H AND KITAGAWA T. (1992). Allelotype of non-small cell carcinoma: comparison between loss of heterozygosity in squamous cell carcinoma and adenocarcinoma. Cancer Res., 52, 2478-2481. 
UZAWA $K$, YOSHIDA $H$, SUSUKI $H$, TANZAWA H, SHIMAZAKI J, SEINO S AND SATO K. (1994). Abnormalities of the adenomatous polyposis coli gene in human oral squamous cell carcinoma. Int. J. Cancer, 58, 814-817.

VAN DER RIET P, NAWROZ H, HRUBAN RH, CORIO R, TOKINO K, KOCH W AND SIDRANSKY D. (1994). Frequent loss of chromosome 9p21-22 early in head and neck cancer progression. Cancer Res., 54, 1156-1158.

VOGELSTEIN B, FEARON ER, KERN SE, HAMILTON SR, PREISINGER AC, NAKAMURA Y AND WHITE R. (1989). Allelotype of colorectal carcinomas. Science, 244, 207-211.
YAMAGUCHI T, TOGUCHIDA J, YAMAMURO T, KOTOURA $Y$ TAKADA N, KAWAGUCHI N, KANEKO Y, NAKAMURA $Y$, SASAKI MS AND ISHIZAKI K. (1992). Allelotype analysis in osteosarcomas: frequent allele loss on $3 \mathrm{q}, 13 \mathrm{q}, 17 \mathrm{p}$ and $18 \mathrm{q}$. Cancer Res., 52, 2419-2423.

YOO GH, XU HJ, BRENNAN JA, WESTRA W. HRUBAN RH, KOCH W, BENEDICT WF AND SIDRANSKY D. (1994). Infrequent inactivation of the retinoblastoma gene despite frequent loss of chromosome $13 q$ in head and neck squamous cell carcinoma. Cancer Res., 54, 4603-4606. 